\title{
AUDIODESCRIÇÃO DE IMAGENS NO LIVRO DIDÁTICO: UM ESTUDO DE CASO COM ESTUDANTES COM BAIXA VISÃO
}

\author{
Silas Nascimento dos SANTOS ${ }^{1}$ \\ Tícia Cassiany Ferro CAVALCANTE ${ }^{2}$
}

\begin{abstract}
Resumo
O presente artigo teve como objetivo verificar como a audiodescrição de imagens estáticas no livro didático dos anos finais do Ensino Fundamental contribuiu para o acesso ao conhecimento de estudantes com baixa visão. Tratou-se de uma pesquisa de abordagem qualitativa, que se configurou como pesquisa do tipo estudo de caso. A construção dos dados correspondeu aos seguintes instrumentos: observação participante e anotações de campo acerca dos sujeitos da pesquisa; seleção de imagens estáticas no livro didático de Língua Portuguesa e entrevistas semiestruturadas com dois estudantes com baixa visão do $7^{\circ}$ ano de uma escola municipal do Recife. Os contributos da análise revelaram que a audiodescrição contribuiu para o acesso ao conhecimento com autonomia, independência e equidade de oportunidades, além da melhoria do repertório imagético e linguístico dos estudantes com baixa visão. Sugeriu-se, ainda, que a audiodescrição é urgente no livro didático, visto que corrobora o aprendizado desses estudantes.
\end{abstract}

Palavras-chave: Educação especial. Audiodescrição. Deficiência visual. Livro didático.

\footnotetext{
1 Mestre em educação pela Universidade Federal de Pernambuco. Professor de Libras do Instituto Federal de Pernambuco (IFPE). ORCID: 0000-0002-3720-554X.

E-mail: silasnascsan@outlook.com

2 Doutora em Psicologia Cognitiva pela Universidade Federal de Pernambuco. Professora Associada III do Departamento de Psicologia e Orientação Educacionais, Centro de Educação, UFPE. Professora do Programa de PósGraduação em Educação, UFPE. ORCID: 0000-0001-8963-9606.

Email: ticiaferro@hotmail.com.
} 


\title{
AUDIO DESCRIPTION OF IMAGES IN THE TEXTBOOK: A CASE STUDY WITH LOW VISION STUDENTS
}

\author{
Silas Nascimento dos SANTOS \\ Tícia Cassiany Ferro CAVALCANTE
}

\begin{abstract}
The present text aims to verify how the audio description of static images in the textbook of the final years of elementary school contributes to students with low vision to have access to knowledge. It is a qualitative research, which is configured as a case study. The construction of the data corresponded to the following instruments: participant observation and field notes about the subjects of the research; selection of static images in the Portuguese Language textbook and semistructured interviews with 2 students with low vision of the 7th grade, from a municipal school in Recife. The contributions of the analysis reveal that the audio description contributes to the access to knowledge with autonomy, independence and fairness of opportunities. In addition, it improves the imagery and linguistic repertoire of students with low vision. It is also suggested that the audio description is urgent in the textbook, since it corroborates for the learning of these students.
\end{abstract}

Keywords: Audio description. Visual impairment. Textbook. 


\title{
AUDIO DESCRIPCIÓN DE IMÁGENES EN EL LIBRO DIDÁCTICO: UN ESTUDIO DE CASO CON ESTUDIANTES CON BAJA VISIÓN
}

\author{
Silas Nascimento dos SANTOS \\ Tícia Cassiany Ferro CAVALCANTE
}

\begin{abstract}
Resumen
El objetivo de este artículo es verificar cómo el audio descripción de imágenes estáticas en el libro didáctico de los últimos años de la enseñanza fundamental contribuyó al acceso al conocimiento de los estudiantes con baja visión. Fue una investigación cualitativa, configurada como un estudio de caso. La construcción de los datos correspondió a los siguientes instrumentos: observación participante y notas de campo sobre los sujetos de investigación; selección de imágenes estáticas en el libro didáctico de lengua portuguesa y entrevistas semi estructuradas a dos alumnos con baja visión del $7^{\circ}$ grado de una escuela municipal de Recife. Los aportes del análisis han revelado que la audio descripción contribuyó al acceso al conocimiento con autonomía, independencia y equidad de oportunidades, además de mejorar el imaginario y el repertorio lingüístico de los estudiantes con baja visión. También sugirió que la audio descripción es urgente en el libro didáctico, ya que es importante para el aprendizaje de estos alumnos.
\end{abstract}

Palabras clave: Educación especial. Descripción de audio. Discapacidad visual. Libro didáctico. 


\section{Introdução}

A audiodescrição como recurso de acessibilidade comunicacional ${ }^{3}$ e empoderativo para o estudante com baixa visão é o que norteia o presente estudo, que teve como objetivo verificar como a audiodescrição de imagens estáticas no livro didático dos anos finais do Ensino Fundamental contribuiu para o acesso ao conhecimento de estudantes com baixa visão. Pretendeu-se, partindo desse objetivo: a) caracterizar as ações de dois estudantes com baixa visão em sala de aula regular; b) analisar como a audiodescrição contribui para o acesso ao conhecimento desses estudantes com baixa visão.

Na sala de aula, todas as formas manifestadas de acessibilidade são cruciais para o estudante com deficiência visual. Em posse do que lhe é de direito, ele pode cessar as dificuldades, sanar as barreiras e exigir mudanças. Portanto, uma das ferramentas de acessibilidade que abre caminhos para as demais é a comunicacional, que favorece práticas includentes e que é, ainda, prevista em lei. Como um dos recursos indisponíveis e importantes para os fins didáticos existentes e que corroboram uma educação comprometida com o respeito às diferenças, destaca-se a audiodescrição.

No Brasil, atualmente, são muitas as pesquisas que trazem à tona a audiodescrição como direito inclusivo e ferramenta acessível propulsora à eliminação da barreira comunicacional (NÓBREGA, 2016; SOUZA, 2017).

Em uma breve revisão de literatura, com base nos dados obtidos no Portal Capes (quarenta e sete produções) e SciELO (quinze produções), foi possível perceber que as pesquisas que focalizam a audiodescrição como recurso de acessibilidade comunicacional para pessoas com deficiência visual têm refletido no âmbito cultural, como o cinema. No trabalho intitulado “Audiodescrição de filmes: experiência, objetividade e acessibilidade cultural,” da autoria de David, Hautequestt e Kastrup (2012), os autores propuseram diretrizes para a construção da audiodescrição; já focalizando no teatro, a pesquisa de Alves (2019), intitulada “Acessibilidade e Teatro: a presença das pessoas com deficiência visual como provocação”, teve como proposta refletir sobre a acessibilidade e o teatro, enfocando na audiodescrição de espetáculo.

No que tange aos estudos de tradução, "Locução e audiodescrição nos estudos de tradução audiovisual”, escrito por Carvalho, Leão e Palmeira (2017), os autores descrevem e analisam locuções realizadas em audiodescrição com ênfase na melodia e no ritmo, com o intuito de aperfeiçoar, cada vez mais, e auxiliar os profissionais a aprimorarem suas vozes de acordo com o gênero proposto. Na pesquisa “Audiodescrição simultânea: propostas metodológicas e práticas”,

\footnotetext{
${ }^{3}$ Sem barreiras nos mais diversos eixos da comunicação, face a face, em língua de sinais, na comunicação virtual e
} escrita, como jornais, livros, revistas, apostilas, entre outros. Sassaki (2010). 
composta por Alves e Teles (2017), as autoras apresentaram uma proposta de pré-roteiro para realização de audiodescrição simultânea, levando em consideração os aportes teóricos, as recomendações dos usuários finais do serviço de audiodescrição e a consultoria de pessoas com deficiência visual.

Vale ressaltar que outras análises também puderam ser encontradas nessa revisão, como a fotografia, a televisão, a ética, o ensino, entre outras. Contudo, no tocante ao contexto escolar, que foi o lugar de nossa pesquisa, na base SciELO, das quinze produções encontradas, apenas uma se aproximou desse debate: “Audiodescrição como recurso de acessibilidade no livro didático de Lîngua Inglesa”, produzido por Eich, Shulz e Pinheiro (2017). As autoras analisaram a relevância das imagens nos livros didáticos para a realização de atividades propostas para estudantes, além de refletirem sobre a audiodescrição e a possibilidade de o recurso proporcionar autonomia nas atividades de pessoas com deficiência visual. Ao final, as autoras reforçaram que a compreensão das imagens eram cruciais para a realização das tarefas e que a audiodescrição é o caminho para a efetiva inclusão escolar.

Quanto ao Portal de Periódicos da Capes, dos quarenta e sete resultados, um apresentou confinidade com o nosso trabalho: “Audiodescrição das imagens dos livros didáticos: uma proposta de análise comunicacional”, da elaboração de Silveira e Bonilla (2019). Na pesquisa, as autoras propuseram a incorporação de aspectos analíticos na audiodescrição a partir dos estudos de Kress e van Leeuwen, com os pressupostos da Gramática Visual, para que estudantes com deficiência visual tivessem subsídios ao interpretarem os aspectos do significado ideológico das imagens. Embora não houvesse presença de imagens e aplicabilidade com estudantes, as pesquisadoras concluíram a necessidade de expandir o estudo, no sentido de incorporar, nas audiodescrições que acompanham as versões digitais das imagens dos livros didáticos, metafunções e análise das estruturas do recurso de acessibilidade.

Em vista das produções científicas apresentadas, notamos lacunas que necessitavam compreender o processo de empoderamento dos estudantes cegos e com baixa visão diante do material didático com audiodescrição mediado em sala de aula.

Para tanto, faz-se necessário que debatamos acerca dos mais diversos pontos de vista que estão relacionados ao conceito da audiodescrição. Inicialmente, trata-se de um recurso que visa à descrição essencial do que está sendo observado para que as pessoas com deficiência visual possam ter acesso. Todavia, não de uma descrição qualquer. Trata-se de um instrumento que contribui para que as pessoas com deficiência visual tenham acesso a toda e qualquer informação. Ou, como bem 
definem Lima, Lima e Vieira (2009, p. 3): a audiodescrição implica em oferecer aos usuários desse serviço as condições de igualdade e oportunidade de acesso ao mundo das imagens, garantindo-lhes o direito de concluírem por si mesmos o que tais imagens significam, a partir de suas experiências, de seu conhecimento de mundo e de sua cognição.

A audiodescrição é, ainda, uma das tantas formas de prover acessibilidade comunicacional no que concerne à cultura, à informação, ao lazer e, mormente, à educação. Para Joel Snyder (2011, p. 2), a audiodescrição “é, acima de tudo, uma técnica de acessibilidade projetada para o benefício das pessoas; de todas elas, incluindo crianças que são cegas ou que tem baixa visão”.

Para Motta (2016), a audiodescrição pode ser interpretada como um recurso de acessibilidade comunicacional que "amplia o entendimento das pessoas com deficiência visual em todos os tipos de eventos, sejam eles acadêmicos, científicos, sociais ou religiosos; espetáculos tais como musicais, espetáculos de dança, circo, peças de teatro, shows, stand ups; produtos audiovisuais e programas de televisão [...]”. (MOTTA, 2016, p. 37).

Entendendo a audiodescrição como uma tecnologia assistiva ${ }^{4}$ na modalidade de serviço, que visa a alcançar a independência, eliminando as barreiras nos mais diversos contextos visuais, compartilhamos de que é, também, a audiodescrição uma forma de oferecer ao sujeito com deficiência visual condições mínimas de ser ativo nas escolhas e nas tomadas de decisão, e, para além, esse recurso vem tornar conhecido aquilo que não podia ser visto, trazendo sentido para o que era inacessível e fazendo da dúvida a certeza do que era indeterminado.

\section{A importância das imagens estáticas no livro didático}

A cada dia, presenciamos a utilização das imagens nos meios de comunicação, como bem destacamos. No fazer pedagógico, elas tomam conta, cotidianamente, das páginas com qualidade estética, tamanhos e formas. Assim, contribuem para os sujeitos que estão se construindo no processo de ensino-aprendizagem. Acerca da presença das imagens, Santaella e Nöth (2014) destacam que:

[...] têm sido meios de expressão da cultura humana desde as pinturas préhistóricas das cavernas, milênios antes do aparecimento do registro da palavra pela escritura. Todavia, enquanto a propagação da palavra humana começou a adquirir dimensões galácticas já no século XV de Gutenberg, a galáxia imagética teria de esperar até o século XX para se desenvolver. Hoje, na idade vídeo e infográfica, nossa vida cotidiana - desde a publicidade televisiva ao café da manhã até as últimas notícias no telejornal da meia-noite - está permeada de mensagens visuais

\footnotetext{
${ }^{4}$ Arsenal de recursos e serviços que contribuem para proporcionar ou ampliar habilidades funcionais de pessoas com deficiência e, consequentemente, propiciar vida independente e inclusão. (BERSH, 2017).
} 
de uma maneira tal que tem levado os apocalípticos da cultura ocidental a deplorar o declínio das mídias verbais (p. 13).

Desde sempre, as imagens, nas mais diferentes formas e culturas, estiveram presentes. No decorrer da nossa história, para Aumont (2012) as imagens possuem três principais relações: a simbólica, no que diz respeito à questão religiosa, em que as imagens serviram de símbolos, representações de divindades etc.; a estética, cuja proposta é a de agradar o espectador; e a epistêmica, que se enlaça com a proposta do livro didático, pois é a que traz informações visuais sobre as coisas que nos cercam, desde um mapa rodoviário a uma carta de baralho, e, com isso, ela recebe a função de conhecimento.

Nesse caminhar de mudanças e transformações, os aparatos provenientes da revolução tecnológica e das mídias digitais, como vídeos no YouTube, links e redes sociais, potencializam, possibilitam e estimulam, cada vez mais, os estudantes. Assim, o livro didático se recria e coexiste nos mais diversos instrumentos, como softwares, livros digitais, os chamados e-books, entre outras formas, e, com a presença de imagens, não poderia ser diferente. Reily (2011, p. 30) nos questiona da variedade dos tipos de imagens presentes no espaço escolar e destaca alguns gêneros: "reflexo no espelho, no vidro, sombras; pegadas, contorno do corpo, marcas do corpo; fotografias: pessoais; em publicações, revistas, materiais de publicidade; ilustrações em livros infantis, em livros de ciência, em manuais [...]”.

É notável a importância da imagem no material didático escolar. É, também, mais que notável o objetivo de correlacioná-la com os conteúdos que são expressos com a proposta pedagógica e a intencionalidade de apresentar ao estudante um mundo desconhecido, ou seja, as imagens são, muitas vezes, complementares das ideias que estão presentes nos livros didáticos, nas atividades. Por essa razão, Motta (2016, p. 35) enfatiza que elas “ilustram, provocam reflexões e emoções, estimulam, motivam, promovem a curiosidade e completam o entendimento do texto”. Belmiro (2000) afirma que:

[...] aprender a ler imagens humaniza o homem, a alfabetização pela imagem é um meio de construir cidadania. Para isso, o aluno deve saber apreciar a imagem dos livros didáticos como arte, reconhecê-la e interpretá-la (e não somente criá-la, como se pontificava nos anos 60). Aqui se identifica um aproveitamento da imagem para o que Barthes chama, em fotografia, de Punctum. É o que toca, punge com seu gesto original, o que cria no espectador uma experiência única que transborda para o imaginário. A estética da recepção traçará um constructo teórico que definirá a importância do sujeito-leitor na produção de sentidos. A riqueza que um estudo da imagem em livros didáticos pode trazer tem correspondência nas atividades de leitura com textos, ao fazer emergir um leitor capaz de atingir diferentes posições de leitura (ou perspectivas/pontos de entrada) (p. 22). 
A imagem modifica o homem, contribui para facilitar o que é ensinado em sala de aula, ajuda na construção da realidade em nossa mente e faz com que estabeleçamos pontes e conexões com o que está disponível ao nosso redor. Assim, inquirimo-nos se, na sala de aula, as imagens têm a mesma importância quando são designadas para os estudantes cegos e com baixa visão, pois, como bem sabemos, inúmeras são as situações que impedem a criança de explorar o universo imagético quando lhe é negada a acessibilidade.

As imagens estáticas como fotos, desenhos, pinturas, cartuns, tirinhas, gráficos, mapas e outras; e as imagens dinâmicas como: vídeos e animações são utilizadas não somente para ilustrar, chamar a atenção e tornar as apresentações mais atraentes, mas também para enfatizar aquilo que os palestrantes ou os professores estão apresentando, complementar o entendimento e torná-lo mais facilmente compreendido ou assimilado. Todos esses recursos visuais têm o seu significado e não são escolhidos aleatoriamente: daí a necessidade de traduzi-los de um meio para outro, transformando as imagens em palavras (MOTTA, 2016, p. 141).

Portanto, para que os estudantes com deficiência visual tenham acesso às imagens estáticas do livro didático, este, necessariamente, precisa ser acessível. Nesse caso, como a funcionalidade da imagem deve ser disponível para todos, apontamos a audiodescrição, enquanto acessibilidade comunicacional, para que o estudante cego ou com baixa visão apreendesse os elementos imagéticos que a atividade proporcionou e, mais que isso, para que pudesse participar com equiparação de oportunidades. Para tanto, apresentaremos a metodologia do estudo, incluindo tipo de pesquisa, caracterização dos estudantes com baixa visual, bem como os procedimentos de coleta e análise dos dados.

\section{Metodologia}

O presente estudo caracterizou-se em trabalho de corte qualitativo, haja vista que, de acordo com Minayo (2013), o cunho dessa abordagem responde a questões bem particulares que não podem ser quantificadas e é, ainda, a “[...] pesquisa que trabalha com o universo dos significados, dos motivos, das aspirações, das crenças, dos valores e das atitudes” (MINAYO, 2013, p. 21). Segundo Bogdan e Biklen (1994, p. 16), esse tipo de pesquisa permite-nos obter “[...] a compreensão dos comportamentos a partir da perspectiva dos sujeitos da investigação”.

Vale destacar que esta pesquisa configurou-se como um Estudo de Caso, tendo em conta que os sujeitos participantes foram estudantes de uma escola municipal do Recife com o maior número de pessoas com deficiência, aqui denominada de escola A, que possuía, na ocasião, um total de 870 estudantes. Destes, 66 eram estudantes com algum tipo de deficiência. 
De acordo com Yin (2001, p. 32), a pesquisa classificada como Estudo de Caso pode ser definida como “[...] uma investigação empírica que investiga um fenômeno contemporâneo dentro de seu contexto da vida real, especialmente quando os limites entre o fenômeno e o contexto não estão claramente definidos”.

Os participantes da pesquisa foram dois estudantes do gênero masculino, do $7^{\circ}$ ano, do Ensino Fundamental, ambos estudantes com baixa visão e da mesma turma. Com o objetivo de mantermos as identidades dos nossos sujeitos em sigilo, utilizamos nomes fictícios: Antônio e Daniel.

Para alcançar nosso objetivo, percorremos um conjunto de técnicas: (i) a observação participante intercalada, semanalmente, em sala de aula, entre os meses de setembro a novembro de 2016; (ii) entrevistas semiestruturadas, após aplicação das atividades dos livros didáticos com acessibilidade comunicacional, com intuito de percebermos os contributos da audiodescrição das imagens. Houve, anteriormente à realização das entrevistas, seleção das imagens presentes nos livros didáticos; ampliação das imagens e roteiro de audiodescrição; além da adaptação das folhas de resposta. Todavia, não foi objetivo do estudo aqui reportado analisar o momento da realização da leitura pelos estudantes com baixa visão nem a folha de respostas. Todas as atividades ocorreram individualmente, no período de novembro a dezembro de 2016.

Respeitando os preceitos éticos da pesquisa com seres humanos, os responsáveis pelos participantes assinaram o Termo de Consentimento Livre e Esclarecido, concordando com o desenvolvimento da pesquisa e também conhecendo todas as etapas do estudo.

\section{Caracterização dos sujeitos}

A dignidade humana desdobra-se em uma infinidade de direitos que são, legalmente, fundamentais para o nosso exercício político e social. O Estatuto da Criança e Adolescente, Lei $n^{\circ}$ 8.069, de 13 de julho de 1990, reconhece a criança como sujeito de direitos. É esta a importância que atribuímos e consideramos que cada sujeito da nossa pesquisa representa.

\section{Sobre Antônio}

O nosso primeiro sujeito de pesquisa foi Antônio. Ele tinha 12 anos e morava com a mãe e a irmã. Era bem tímido, de poucos amigos em sala de aula, de pouca conversa e sentava-se, sempre, na primeira carteira, na fileira do meio. Ele era branco e magro. Tinha 1,50 m. Os cabelos eram pretos e curtos. Eles estavam penteados para trás. Antônio tinha as sobrancelhas finas e os olhos castanhos e puxados. As orelhas eram pequenas, e o nariz, médio e arredondado. Tinha a boca 
pequena, lábios finos e rosados. Usava óculos de grau pretos e quadrados. Vestia camiseta branca de mangas azuis e calça jeans. Calçava um par de tênis preto e cinza. Ele era pessoa com baixa visão, com laudo médico apresentado pela Fundação Altino Ventura ${ }^{5}$. Antônio usava óculos de grau com lentes grossas e olhava para a lousa e os materiais didáticos com certa dificuldade.

Antônio gostava muito de estudar, pois isso, segundo ele, contribuía para aprender, bem como para se desenvolver cada vez mais. A escola, para o nosso sujeito, era muito boa, os professores e as professoras também eram, pois ensinavam muito bem, e os amigos, muito legais para brincar.

Geografia era o componente curricular de que Antônio mais gostava, devido ao uso de mapas, à orientação e à localização geográfica fornecida pelo Global Positioning System (GPS), que significa, em português, Sistema de Posicionamento Global. Matemática era o componente de que ele menos gostava, porque era muito complicado fazer cálculos. Antônio não era muito fã de leitura. Todavia, gostava muito de livros de história e das histórias em quadrinhos. Nas leituras que ele realizava, não sentia dificuldades que o impedissem de compreender o texto e os demais elementos que o compunha.

\section{Sobre Daniel}

Daniel foi o segundo participante da pesquisa. Ele tinha 12 anos e vivia com a avó. Era moreno e magro. Tinha 1,50 m e cabelos pretos e curtos. As sobrancelhas eram grossas e os olhos, castanhos e arredondados. As orelhas de Daniel eram pequenas, e tinha nariz médio e arredondado. Ele tinha a boca pequena, lábios grossos e rosados. Usava óculos de grau pretos e arredondados. Vestia camiseta branca e calça jeans. Calçava um par de tênis preto, vermelho e branco.

Ele também era pessoa com baixa visão. De acordo com a professora do Atendimento Educacional Especializado da escola, Daniel apresentava dificuldade visual e estava em avaliação pela Fundação Altino Ventura. Ele usava óculos de grau com lentes bastante grossas; em certos momentos, olhava para a lousa com certa dificuldade e aproximava-se bastante do material didático. Era um pouco tímido, sentava-se, sempre, na fileira do meio, na segunda carteira, depois de Antônio.

Daniel gostava muito de estudar, pois acreditava que o estudo podia promover um futuro melhor. Quanto à escola, ele achava que não era tão boa por causa dos colegas de sala, que

\footnotetext{
${ }^{5}$ Fundação Altino Ventura (FAV) é uma instituição filantrópica, de utilidade pública municipal, estadual e federal. A FAV trabalha com projetos de combate à cegueira e reabilitação visual. A missão da instituição é promover a saúde ocular e das múltiplas deficiências; reabilitar/habilitar pacientes com deficiências múltiplas; contribuir para a inclusão social dos pacientes; e fomentar o ensino e a pesquisa científica. Disponível em: http://www.fundacaoaltinoventura.com.br. Acesso em 18 de julho de 2020.
} 
zombavam dele e não eram tão legais, embora existissem colegas, um total de cinco, segundo ele, com quem conversasse, partilhasse e dialogasse.

Para o nosso sujeito, os professores e as professoras também eram muito legais e ensinavam muito bem. O componente curricular que Daniel mais gostava era Matemática. Já o que ele menos gostava, História, era em decorrência dos muitos fatos e acontecimentos que o deixavam confuso. Daniel gostava muito de ler. Lia de tudo um pouco, mas o momento de leitura se dava quando estava sem internet ou sem tarefas a fazer. Assim como Antônio, Daniel destacava que, ao realizar as leituras que sentia prazer e encantamento, não havia barreiras que o impedissem de entender o texto lido.

\section{Análise dos dados}

A análise dos dados foi dividida em 2 momentos: a) análise das observações, baseada na teoria da inclusão educacional, em autores como Ainscow (1995), Silva (2014), entre outros; b) análise das entrevistas, pautada na análise de conteúdo, técnica de tratamento proposta por Bardin (2011), em que apresentamos imagens, audiodescrições realizadas por nós e os relatos suscitados. Essa técnica de análise fez-se de suma importância, pois, como reforça Oliveira et. al (2003), na educação, a análise de conteúdo é um instrumento de muita utilidade, tendo em vista que ajuda o educador a retirar dos dados que foram coletados, como entrevistas, questionários, artigos de jornais, entre outros, conteúdos manifestos ou latentes ao que foi pesquisado.

\section{Análise das observações: traçando caminhos para o aprendizado}

O direito à educação implica aprendizado, partilha de saberes, convivência social, interações e desenvolvimento humano. A escola é o espaço que, muitas vezes, oferece todas essas implicações, e o Ensino Fundamental, que tem duração mínima de 9 anos, é um importante ciclo na vida dos estudantes, pois é a partir dele, de acordo com a Seção III da Lei de Diretrizes e Bases da Educação (LDB/1996), art. 32, que acontece a formação básica do ser cidadão, dos conhecimentos para o domínio da leitura, da escrita, do cálculo; da sociedade como um todo, nos aspectos tecnológicos, políticos; na aquisição dos mais diversos conhecimentos; na solidariedade humana e no vínculo familiar (BRASIL, 1996).

E é em sala de aula, lugar sagrado e de comunhão, que também se ensina, se aprende e se constrói. Por essa razão, com o intuito de estabelecer confiança, ganhar acesso, conhecer a rotina, 
perceber as relações e os comportamentos dos estudantes com baixa visão diante da comunidade escolar e do material didático, realizamos observações que serão detalhadas nos quadros a seguir.

\section{Quadro 1 - Antônio, Daniel e as primeiras impressões}

\begin{tabular}{|c|}
\hline $\begin{array}{c}\text { Data: } 11 / 10 / 16-7^{\circ} \text { ano } \\
\text { Componente: Língua Portuguesa } \\
\text { Observação/número: } 01-2 \text { aulas }-13 \mathrm{~h} 30 \text { às } 15 \mathrm{~h} 20\end{array}$ \\
\hline $\begin{array}{l}\text { Primeiro dia de observação. Destaquei, mais uma vez, para a professora, quais eram os objetivos da pesquisa e os } \\
\text { propósitos de estar presente durante as aulas. De modo breve, a professora apresentou-me para os estudantes. Um } \\
\text { total de } 23 \text { estudantes estava em sala. Eram } 10 \text { meninas e } 13 \text { meninos. } \\
\text { A professora, depois de conter os ânimos dos estudantes, iniciou um ditado de palavras. Cerca de } 20 \text { palavras. Foi } \\
\text { possível perceber que Antônio e Daniel, no decorrer do ditado das palavras, aproximaram-se bastante do caderno } \\
\text { para escrevê-las. }\end{array}$ \\
\hline $\begin{array}{l}\text { No momento das correções, a professora solicitou que os estudantes fossem até a lousa e escrevessem a palavra de } \\
\text { acordo com suas anotações. De um por um, alguns escreveram as palavras grafadas de maneira incorreta, } \\
\text { apagavam e reescreviam de maneira correta. Outros estudantes gritavam, davam pistas, jogavam bolinhas de papel } \\
\text { e olhavam para o caderno do colega ao lado. }\end{array}$ \\
\hline $\begin{array}{l}\text { Na lousa, com o rosto bem aproximado, Antônio escreveu a palavra “acento”. Alguns estudantes gritavam, outros } \\
\text { sorriam. A professora perguntou para a turma se a palavra estava correta e a substituiu, assim, por “assento”. }\end{array}$ \\
\hline $\begin{array}{l}\text { Daniel foi até a lousa. Rente ao quadro, escreveu “atravessar”. A professora perguntou para a turma se a palavra } \\
\text { estava correta. A turma consentiu. A professora deu continuidade à aula com o conteúdo de Homônimos, fez uma } \\
\text { explanação e realizou um exercício para que os estudantes estabelecessem relação das palavras. }\end{array}$ \\
\hline $\begin{array}{l}\text { Cabe destacar que os estudantes não usavam quaisquer recursos que promovessem autonomia na execução das } \\
\text { tarefas. Além disso, a professora não proferiu quaisquer orientações específicas. }\end{array}$ \\
\hline
\end{tabular}

Fonte: registros do diário de campo. Elaboração do autor (2016).

Estar presente em sala de aula não é sinônimo de aprender. Assim como ter estudante com deficiência visual na escola não é sinônimo de incluir. Foi possível, nesse primeiro momento, percebermos que Antônio e Daniel apresentavam características de pessoas com deficiência visual, especificamente a baixa visão, tendo em vista a aproximação do caderno, ao escrever, e a maneira com que se dispuseram frente à lousa. É importante frisar que, mesmo com o uso dos óculos, os sujeitos eram pessoas com deficiência visual, tendo em vista que as lentes são recursos ópticos que contribuem para o conforto e desempenho visual.

A inclusão requer planejamento e adaptação necessária para que os estudantes com deficiência sejam atendidos de acordo com suas características. Silva (2014, p. 43) aconselha que devemos garantir “[...] que, em toda atividade realizada em sala de aula e/ou extraescolar, sejam feitas acomodações para que todos os alunos, inclusive aqueles com deficiência, possam 
participar conforme suas potencialidades e possibilidades [...]”, o que é passível de oferta para que Antônio e Daniel, mesmo em atividades objetivas como essa, não apresentassem dificuldades que os limitassem.

Masini (2007) ressalta que, se trabalhamos para o processo educacional de estudantes com baixa visão, para que estes alcancem a autonomia e inclusão social, nos mais diversos espaços sociais, estaremos, dessa forma, buscando condições para que eles se desenvolvam e aprendam.

É mister destacar que não exigimos preparo docente para atuar frente às dificuldades trazidas pelos estudantes, mas, sim, observar e conhecer, como ressaltam Solér et. al. (2007), a rotina das aulas e as necessidades dos estudantes com baixa visão diante da escola regular. Frente aos recursos e às orientações que podem contribuir para os estudantes com baixa visão, de acordo com os autores supraditos, destacamos dois de grande importância: a necessidade de ampliação de textos, livros e letras e o uso do caderno com pauta ampliada, para que o estudante desenvolva suas potencialidades nos mais diversos aspectos.

Destacamos que, na situação observada, Quadro 1, não houve adequação alguma do material didático. Além disso, nenhum dos sujeitos realizou suas atividades em pautas ampliadas. Assim, no Quadro 2, a seguir, foi possível percebermos as barreiras enfrentadas pelos estudantes Antônio e Daniel frente ao livro didático.

\title{
Quadro 2 - Antônio, Daniel e a urgência da acessibilidade comunicacional em sala de aula
}

\author{
Data: 09/11/16 $-7^{\circ}$ ano \\ Componente: Língua Portuguesa
}

Observação/número: $02-2$ aulas -13 h30 às $15 h 20$

A professora iniciou a aula falando sobre os gêneros textuais. Questionou a turma sobre o significado do verbete “tribo”. Alguns estudantes responderam: “grupo de índios, professora! São os indígenas!”. Em posse de um dicionário, a professora leu o significado da palavra. Em seguida, perguntou se a turma sabia o que era reportagem. Muitos falaram acerca da notícia, como exemplo. Ela solicitou que os estudantes abrissem os livros para dar início à leitura em grupo. O texto era sobre estilos, identidades e gostos musicais variados. Daniel iniciou a leitura. Com o rosto bem próximo ao livro didático, leu em voz alta para o grupo. Antônio, com muita dificuldade, inclinou a cabeça para a direita, na tentativa do melhor ângulo para a leitura. Pulou algumas palavras e alternou o tom de voz. A professora solicitou que ele lesse mais alto. Ao fim da leitura, Daniel fez alguns questionamentos acerca de algumas palavras do texto. A professora respondeu, fez a leitura das imagens para os estudantes e propôs atividades. Na lousa, colocou: qual é a sua tribo? Na correção do exercício, ela pediu que os estudantes lessem, em voz alta, suas respostas. Antônio falou a respeito da tribo dos esqueitistas e destacou o gosto pelo Hip-hop. A professora surpreendeu-se com a resposta, ressaltou a timidez do sujeito e endossou que 
não imaginaria tais preferencias do estudante. Nos momentos finais da aula, em referência às imagens presentes na atividade, a professora destacou: “às vezes você lê, mas nem sempre o que se lê se entende o que está escrito. É preciso entender as imagens e o que elas podem falar mais sobre o que está escrito”.

Fonte: registros do diário de campo. Elaboração do autor (2016).

Muitas são as dificuldades enfrentadas por estudantes com deficiência visual na escola, como as barreiras físicas, que impedem a orientação e a mobilidade, e as barreiras para a aprendizagem, que devem ser removidas, considerando as características de cada sujeito (CARVALHO, 2003). Como bem sabemos, as necessidades educacionais divergem de estudante para estudante, como foram os casos de Antônio e Daniel. Entre tantas observações, nessa em especial, foi possível perceber o entusiasmo dos sujeitos no diálogo com a professora e nas respostas orais dos exercícios. No entanto, cabe reconhecer que as dificuldades frente ao livro didático e no desempenho da leitura também se fizeram, mais uma vez, presentes, como a inclinação de cabeça de Antônio e a proximidade do rosto de Daniel no livro.

Nesse sentido, Ainscow (1995) afirma que o professor deve ser estimulado a utilizar um recurso natural, que é pouco usado e que apoia a aprendizagem em sala de aula: os próprios estudantes.

Em cada classe os alunos representam uma fonte rica de experiências, de inspiração, de desafio e de apoio que, se for utilizada, pode insuflar uma imensa energia adicional nas tarefas e actividades em curso. No entanto, tudo isto depende da capacidade do professor em aproveitar esta energia. Isto é, em parte, uma questão de atitude, dependendo do reconhecimento de que os alunos têm a capacidade para contribuir para a respectiva aprendizagem; reconhecendo igualmente que, de facto, a aprendizagem é, em grande medida, um processo social (AINSCOW, 1995, p.5).

É possível, em sala de aula, que o professor proponha melhores maneiras de mediar o conhecimento. Para tanto, formas e estratégias que motivem a aprendizagem dos estudantes são necessárias, como, por exemplo, o uso das novas tecnologias da educação. Desse feito, a reflexão da professora, no final da aula, reafirmou, nas linhas subjacentes, o quanto se faz importante a acessibilidade comunicacional no material didático para pessoas com deficiência visual e o quanto se faz imprescindível a ampliação de material, mudanças e adaptações curriculares para que empecilhos possam ser obstruídos. E, em se tratando de imagens estáticas no livro didático, o quanto a audiodescrição pode remover barreiras, tornar a aprendizagem bem mais interessante e aliar-se às práticas docentes. 


\section{Análise das entrevistas: contributos para uma aprendizagem de escolha e de poder}

As imagens presentes no livro didático promovem significados, e a acessibilidade comunicacional, enquanto recurso propulsor na educação, permite, aos estudantes, perceberem esses elementos que auxiliam a compreensão imagética e potencializam suas possibilidades de aprendizado. Nesse sentido, Rodrigues (2001) acentua que:

$\mathrm{O}$ ato de formar o ser humano se dá em dois planos distintos e complementares: um de fora para dentro e outro, de dentro para fora. Pelo primeiro, ele 'precisa ser educado' por uma ação que lhe é externa, de modo similar à ação dos escultores que tomam uma matéria informe qualquer, uma madeira, uma pedra, ou um pedaço de mármore, e criam a partir dela um outro ser. Assim como não se deve esperar que um objeto escultural apareça de modo espontâneo, também não se deve esperar que o ser humano seja fruto de um processo de auto-criação. [...] No segundo plano, educar compreende acionar os meios intelectuais de cada educando para que ele seja capaz de assumir o pleno uso de suas potencialidades físicas, intelectuais e morais para conduzir a continuidade de sua própria formação. Esta é uma das condições para que ele se construa como sujeito livre e independente daqueles que o estão gerando como ser humano. A Educação possibilita a cada indivíduo que adquira a capacidade de auto-conduzir o seu próprio processo formativo (RODRIGUES, 2001, p. 240. Grifos nossos).

Levando em consideração que a audiodescrição potencializava o empoderamento dos sujeitos Antônio e Daniel e os tornava independentes, foi possível identificarmos a contribuição da audiodescrição no processo de compreensão dos exercícios já respondidos pelos sujeitos. Em uma das atividades audiodescritas de Antônio, conforme quadro abaixo, que discutiu a respeito dos problemas ambientais, quando questionado se a imagem foi contributiva para a resolução da atividade, ele afirmou que sim e que a audiodescrição tornou claro o que estava acontecendo na imagem. E, quando inquirimos de que maneira o exercício seria respondido, com a omissão da audiodescrição, Antônio endossou: “[...] acho que errado! Porque eu ia ficar sem entender... sem a explicação[...]”.

Nesse sentido, para o sujeito, a oferta da acessibilidade, no livro didático, não só facilitou, mas também contribuiu efetivamente para as suas tomadas de decisão. Antônio reforçou dizendo que a audiodescrição estava “[...] explicando o que estava acontecendo, um bocado de homem... é um em cima do outro, querendo pegar o sapato... uma fábrica soltando a fumaça branca, prédios [...]”. 


\title{
Quadro 3 - Atividade 1 - Antônio
}
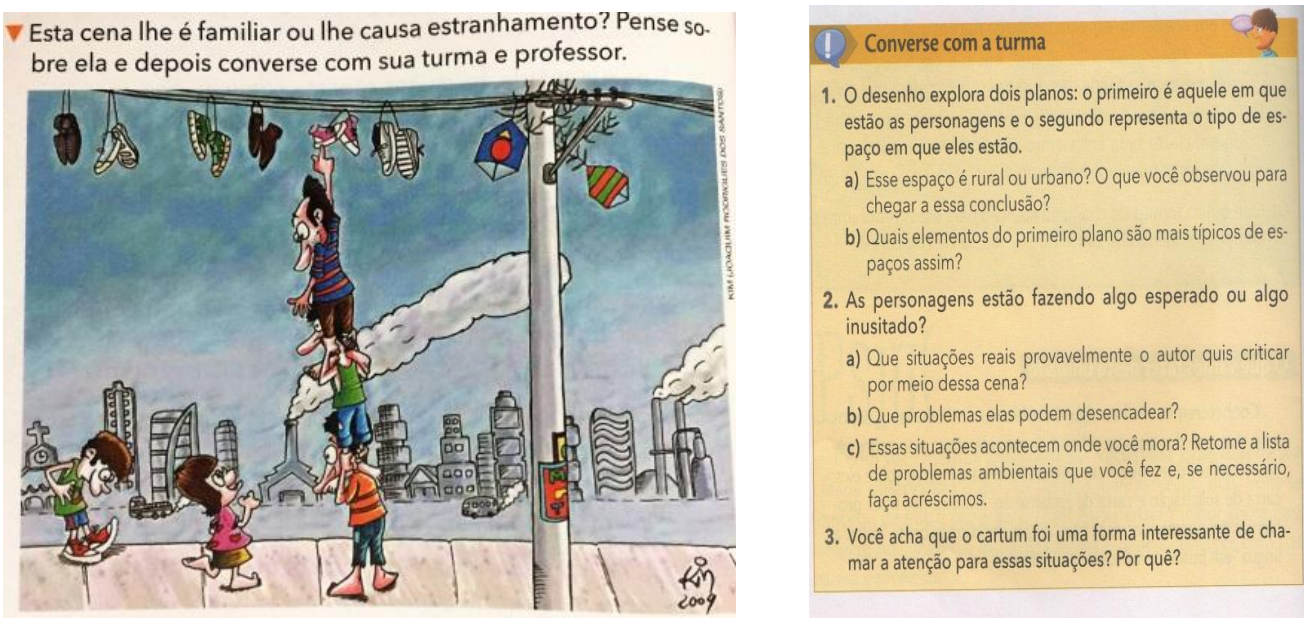

Imagens 1 e 2 - Singular \& Plural: leitura, produção e estudos de linguagem, $7^{\circ}$ ano, p. 116. Capítulo 1. Pelas ruas da cidade: problemas ambientais.

\begin{abstract}
Notas proêmias - Cartum quadrado, colorido, de um grupo de pessoas em uma calçada, do cartunista Joaquim Rodrigues dos Santos, mais conhecido como Kim. Cartum é o gênero em que textos feitos de desenhos, às vezes, acompanhados de pequenos textos verbais, tratam de temas atuais com criticidade e efeitos de humor.

Audiodescrição - É dia. Em uma calçada, um grupo de pessoas está próximo a um poste. À esquerda, um garoto branco olha para os pés. Ele veste camiseta verde e bermuda azul. Calça sapatos vermelhos. Ao lado do garoto, há uma garota. Ela veste blusa rosa e saia marrom. Está descalça. Olha para cima, em direção a três homens. Eles estão descalços e empilhados, como se fossem uma escada, próximos a fios de alta tensão. Nos fios, há pipas coloridas e pares de sapatos embaraçados. Do alto, um dos homens olha para a garota e aponta para um par de sapatos rosa. Ao longe, há igreja e prédios. Carros e fábricas liberam rastros de fumaça branca.
\end{abstract}

Fonte: registros das audiodescrições realizadas. Elaboração do autor (2016).

Tangente à atividade relacionada a duas fotografias do filme “ABC do Amor”, do ano de 2005, presentes no quadro a seguir, de acordo com Daniel, a imagem foi fundamental para a compreensão do exercício. Todavia, com a acessibilidade comunicacional, tornou-se “[...] um pouco mais fácil! [...]”, pois “[...] deu mais explicação do que estava acontecendo nas imagens [...] mais detalhes! [...]”. Daniel complementou acerca das contribuições para a atividade dizendo que: “[...] na imagem não diz sobre os garotos, na audiodescrição diz onde eles moram [...] e a primeira imagem não diz, só mostra eles lá no cenário e na audiodescrição fala onde eles moram [...] O que eles estão fazendo e o que eles fazem no dia a dia! [...]”. 


\section{Quadro 4 - Atividade 1 - Daniel}
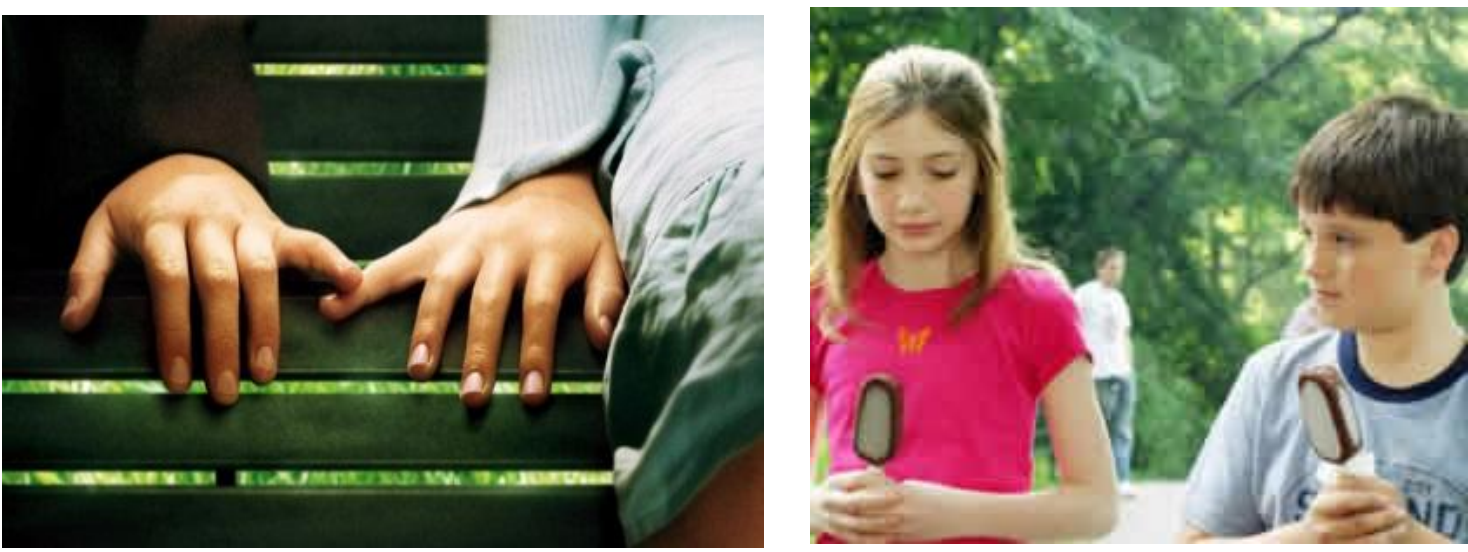

\section{Converse com a turma}

1. As imagens que aparecem nesta abertura são cenas do filme $A B C$ do amor.

a) $O$ que esse título dado ao filme pode significar?

b) Considerando esse significado, que leitura você faz de cada uma das imagens?

2. Qual parece ser o "clima" entre as duas personagens, na imagem em que eles tomam sorvete?

Imagens 1 e 2 - Singular \& Plural: leitura, produção e estudos de linguagem, $7^{\circ}$ ano, p. 176.

Capítulo 2. Instantes Poéticos.

Notas proêmias - Fotografias coloridas, em paisagem, de cena do filme “ABC do amor”, da direção de Mark Levin, EUA, 2005.

Audiodescrição - Fotografia 1 - É dia. Em um banco de madeira verde, há dois garotos. Um menino e uma menina. Eles estão lado a lado e têm uma das mãos apoiadas sobre o banco. As mãos estão abertas. Com o dedo mindinho, o garoto toca a ponta do dedo mindinho da garota.

Fotografia 2 - Em um parque arborizado, num dia claro, há um casal de pré-adolescentes. Eles têm 10 anos. Estão lado a lado e tomam sorvete de chocolate. À esquerda, está a garota. Ela é branca, tem os cabelos castanho-claros na altura dos ombros e veste blusa rosa. Olha para baixo. À direita, está o garoto. Ele é branco, tem os cabelos castanho-escuros e veste camisa azul. Ele olha para a garota.

Fonte: registros das audiodescrições realizadas. Elaboração do autor (2016).

Foi possível inferirmos que as "explicações”, “detalhes” e “facilidades” que se aplicavam à audiodescrição, nos relatos dos sujeitos, foram reflexos do usufruto, na prática, dos direitos essenciais e educacionais que contribuem para autonomia, independência, para as oportunidades de aprendizagem e de acesso ao conhecimento; para a melhoria do repertório imagético e linguístico e, sobretudo, para o empoderamento, como veremos na discussão referendada nos Quadros 5, 6 e 7. 


\section{Quadro 5 - Atividade 2 - Antônio e Daniel}

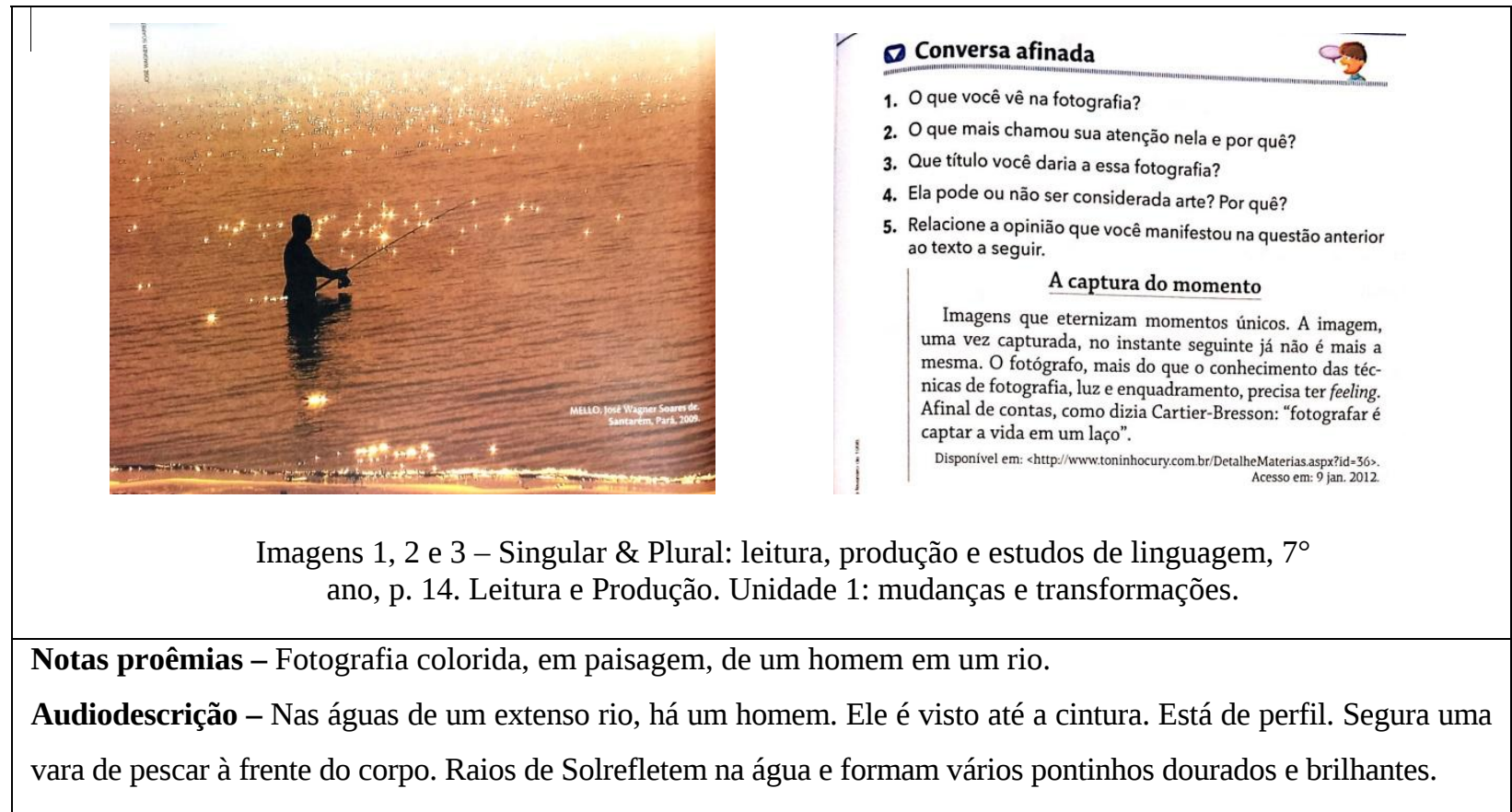

Fonte: registros das audiodescrições realizadas. Elaboração do autor (2016).

Antônio, após a resolução do exercício com audiodescrição do Quadro 5, destacou sobre o recurso: “Achei boa e a paisagem também! Achei bonita! Tem um homem, tem um rio e raios de Sol refletindo. Eu não sabia que essa partes daqui eram o Sol, foi quando eu tava (sic) lendo [...] Porque com o texto eu posso entender melhor a imagem". O "texto" que Antônio se referia foi a oferta da audiodescrição que, como foi possível visualizarmos, trouxe contributos para o discurso imagético do sujeito.

Nos relatos de Daniel, a atividade: “[...] foi um pouquinho fácil, por causa da audiodescrição! [...]”. Ele continuou: “[...] pra poder entender um pouquinho dessas imagens aqui [...] Eu não entendi muito a imagem, não. Só tinha visto o rio e o homem. Só [...]”. E destacou sobre a audiodescrição: “[...] foi boa. Deu mais detalhe sobre a imagem. Que essas luzinhas que estavam saindo da água era (sic) raios do Sol, raios solar. Ela explicou mais sobre a imagem, o que estava acontecendo, e o que tinha na imagem”.

Assim como o sujeito Antônio, Daniel destacou informações relevantes que foram essenciais não só para a aprendizagem, mas também para o entendimento na correlação da atividade. Vale frisar que a proposta da audiodescrição não é explicar ou facilitar atividades para os estudantes com baixa visão, mas tornar claro e evidente, por meio da tradução intersemiótica, elementos que, de alguma forma, são suprimidos em decorrência da falta de acessibilidade no livro didático, inclusive 
como bem afirma Ribeiro (2011, p.122): “[...] porque a técnica amplia o conhecimento do que o sujeito já leu”.

\section{Quadro 6 - Atividade 3 - Antônio e Daniel}
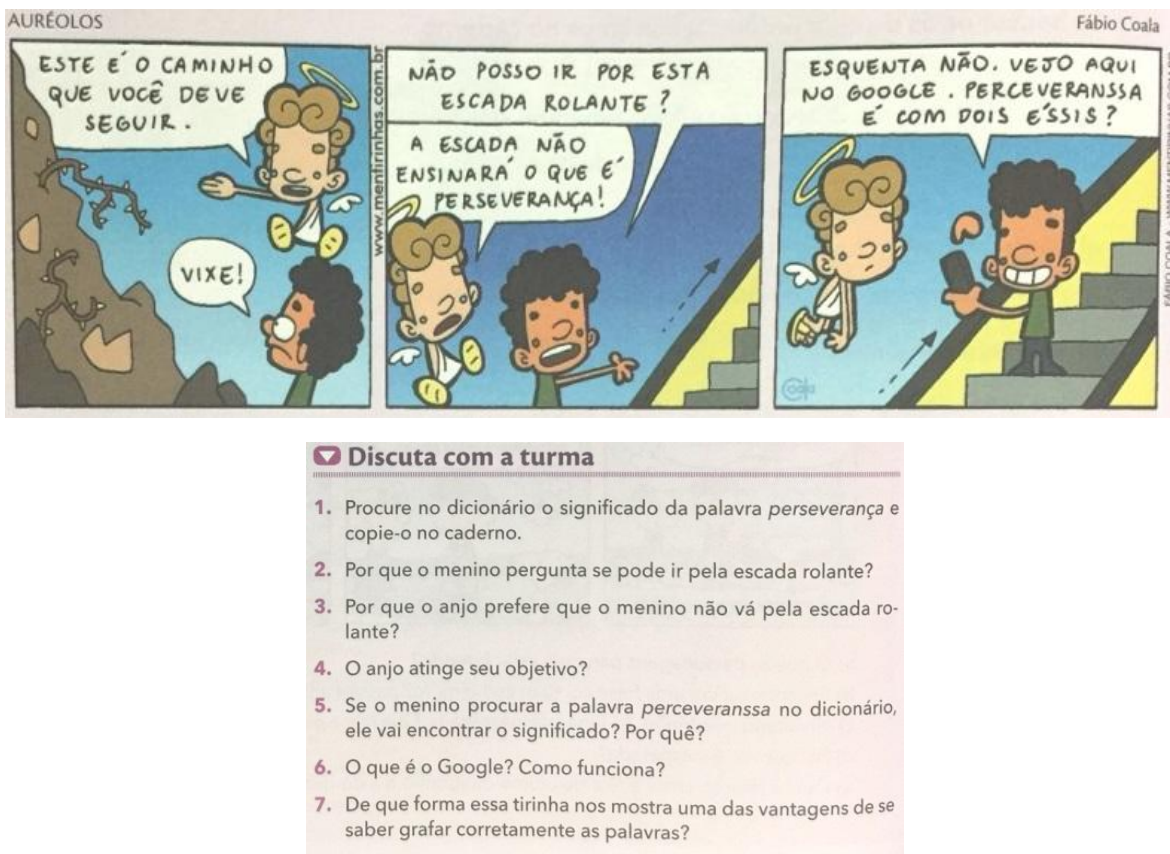

Imagens 1 e 2 - Singular \& Plural: leitura, produção e estudos de linguagem, $7^{\circ}$ ano, p. 276. Unidade 3. Ortografia e pontuação.

Notas proêmias - Tirinha colorida, em 3 (três) quadrinhos, do autor Fábio Coala, da série Auréolos. A tirinha é sobre um anjinho loiro e um menino moreno. O anjo tem os cabelos encaracolados e olhos azuis. Veste um manto branco e calça sandálias amarelas. O menino tem os cabelos pretos e volumosos. Os olhos são pretos. Ele veste camisa verde e calça preta.

Audiodescrição - Quadrinho 1 - É dia. Do alto de uma montanha rochosa e com galhos espinhosos, o anjo aponta e diz: ESTE É O CAMINHO QUE VOCÊ DEVE SEGUIR. Com os olhos arregalados, o menino fala: VIXE!

Quadrinho 2 - De frente para uma escada, o menino diz: NÃO POSSO IR POR ESTA ESCADA ROLANTE? O anjo, de boca aberta, responde: A ESCADA NÃO ENSINARÁ O QUE É PERSEVERANÇA!

Quadrinho 3 - Do alto da escada, o menino, com um celular preto na mão, diz: ESQUENTA NÃO. VEJO AQUI NO GOOGLE. PERCEVERANSSA É COM DOIS ÉSSIS? O anjo, de ombros caídos, olha para o menino.

Fonte: registros das audiodescrições realizadas. Elaboração do autor (2016).

Posteriormente à atividade do Quadro 6, o sujeito Antônio destacou que a atividade promovida com o recurso da audiodescrição foi “fácil” e que gostou da tirinha. Destacou também que o anjo estava "triste” e reforçou: porque ele queria que “[...] ele subisse pela montanha e o menino quis pela escada rolante”. Asseverou que a oferta da audiodescrição foi contributiva para que pudesse entender os elementos que permearam a atividade. 
Daniel ressaltou que o grau de dificuldade da atividade “[...] foi mais ou menos”, todavia, com o recurso da audiodescrição, “[...] foi melhor!”. Quando questionamos de que maneira a audiodescrição contribuiu pra que ele chegasse à conclusão sobre a imagem, o sujeito afirmou: “[...] sobre o que o anjinho tava (sic) querendo que o menino fizesse [...], dando detalhes sobre o que estava acontecendo com o anjinho e com o menino!”.

Motta (2016) nos anuncia que atividades como tirinhas, charges, cartuns são muito importantes para que os estudantes com deficiência visual ampliem seus entendimentos e sua visão crítica. A autora ratifica, ainda, que o conhecimento da linguagem trazida nos quadrinhos é indispensável para que os estudantes decodifiquem as diversas mensagens presentes. Em vista disso, alteamos o relato de Antônio, quando nos alertou que o anjo estava triste. A audiodescrição denunciou a incerteza e permitiu que Antônio realizasse a construção da imagem e a formação do conceito.

\section{Quadro 7 - Atividade 4 - Antônio e Daniel}
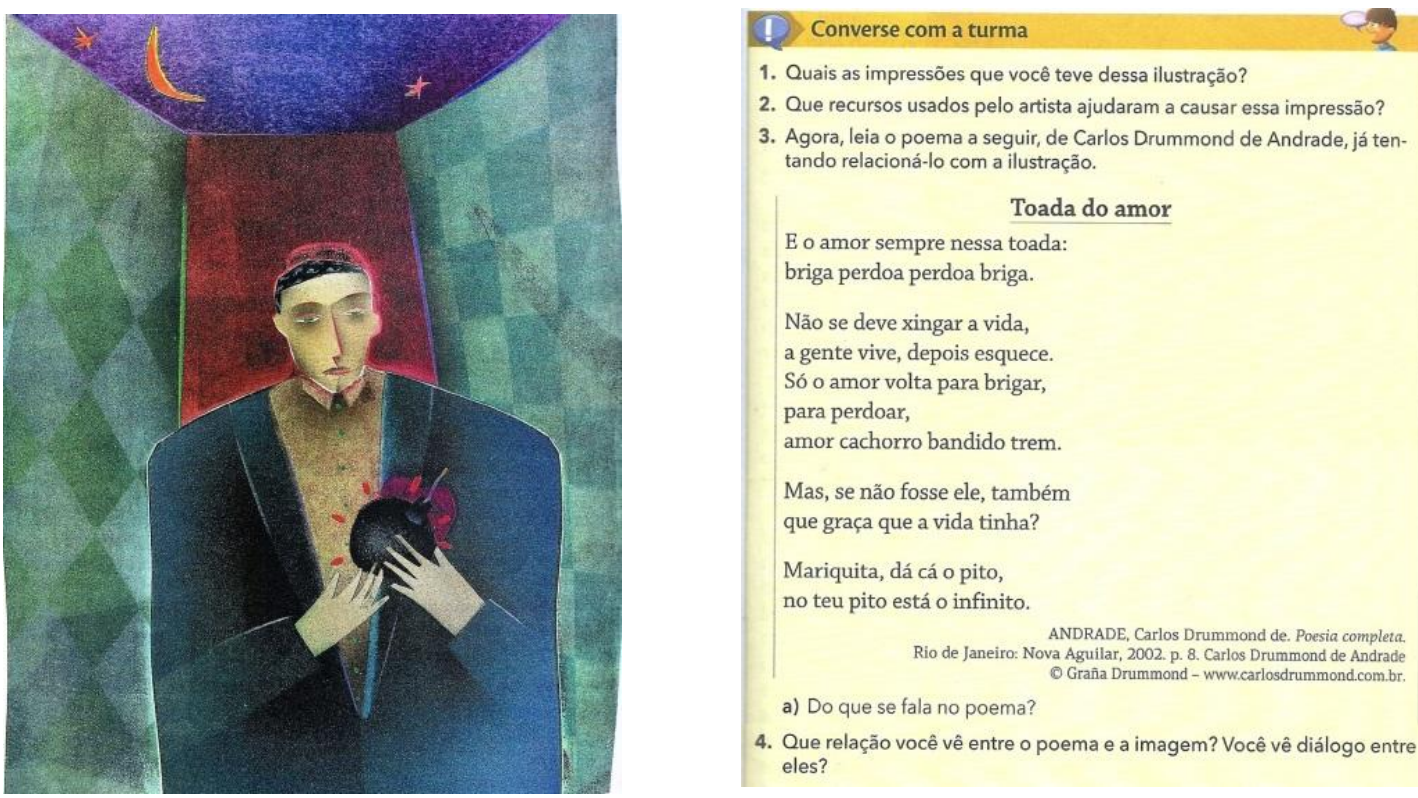

Imagens 1 e 2 - Singular \& Plural: leitura, produção e estudos de linguagem, $7^{\circ}$ ano, p. 40. Capítulo 2. Um mundo de emoções: o primeiro beijo, as indecisões, as decepções..

Notas proêmias - Desenho colorido de um homem forte e moreno.

Audiodescrição - Sob um céu estrelado e com uma meia-lua, há um homem forte e moreno. Ele tem os cabelos pretos e curtos. Os olhos são puxados e verdes. Ele está sério. Olha para baixo. Veste um paletó azul sobre uma camisa marrom. Está com as mãos sobre o peito esquerdo. Entre elas, há uma bomba.

Fonte: registros das audiodescrições realizadas. Elaboração do autor (2016). 
Assim como na atividade do quadro anterior, foi possível compreendermos que a audiodescrição propiciou aos sujeitos, Antônio e Daniel, que eles mesmos destacassem suas opiniões, tirassem suas próprias conclusões acerca do evento visual trazido no livro didático. Antônio legitimou que a audiodescrição possibilitou a compreensão do exercício. Tendo em vista que antes “[...] não tinha percebido a Lua e as estrelas direito”, o sujeito reforçou que, entre a própria imagem e o recurso da audiodescrição, esta seria sua escolha, pois a audiodescrição mostrou-lhe a imagem “[...] explicando como tá sendo [...] um homem sentado, segurando uma bomba [...] próxima do seu peito em uma noite estrelada”. Nesse excerto, a audiodescrição proporcionou aos estudantes a apropriação do objetivo comunicacional das imagens e lhes permitiu “uma maior autonomia no exercício do conhecimento subjetivo”, como salientam Silveira e Bonilla (2019, p. 13).

O sujeito Daniel depreendeu que a atividade, por causa do recurso acessível, “[...] foi fácil”. E corroborou destacando que a audiodescrição, além de contribuir para a solução da atividade, “[...] Foi boa, só que foi um pouco pequena”. Por fim, assim como Antônio, Daniel defendeu que, para que ele pudesse obter melhores resultados, a audiodescrição seria o implemento dos exercícios.

As informações visuais para os estudantes com deficiência visual, como constatamos, podem empoderá-los quando adaptadas de maneira acessível no livro didático escolar. Ribeiro (2011) certifica nos dizendo que:

Os constructos imagéticos da áudio-descrição que, por sua vez, for apresentada em uma obra áudio-descrita, possibilitam ao sujeito acesso à informação e assim ampliá-las em suas zonas laborais na aquisição de um novo conhecimento. Essa apropriação laboral da imagem áudio-descrita traz ao sujeito um mediador externo, que uma vez possibilita novas possibilidades de conhecimento. Ao se relacionar tais elementos com a educação, esta deve prezar pela inserção social e buscar novas formas de não limitar o educando nas apropriações de novos conhecimentos (RIBEIRO, 2011, p. 69).

A audiodescrição de imagens, no livro didático, nessa perspectiva, ofereceu, à medida que os sujeitos tiveram suas oportunidades equiparadas, condições de desraizar a inacessibilidade entre o texto e a imagem e, mais que isso, oferecer conjunturas para acessar o que não era conhecido. Desse feito, os relatos dos sujeitos Antônio e Daniel revelaram e suscitaram as dificuldades no acesso às imagens presentes no livro didático. Não enxergar direito, não perceber detalhes e não ter certeza dos eventos visuais, sobretudo no momento das atividades, são características que podem levar os estudantes ao equívoco e, consequentemente, ao não aprendizado, pois a inexistência da acessibilidade nas imagens, conforme Lima e Lima (2011, p. 11), “[...] leva a criança com 
deficiência a uma situação de incapacidade para o aprender; limite para o seu lazer e impedimento ao conhecimento de forma geral”.

Assim sendo, apropriar-se de alternativas pedagógicas que promovam o aprendizado da diversidade é apoderar-se da possibilidade de agir diante das escolhas e ter poder sobre elas. Além disso, como acentuam Eich, Schulz e Pinheiro (2017), se o material didático apresentar a audiodescrição como recurso de acessibilidade comunicacional, a chance de desenvolvimento dos estudantes com deficiência visual crescerá, a independência deles ficará evidente e a autonomia na realização das atividades se fará ainda mais presente, sem ajudas constantes de professores, monitores ou colegas.

\section{Considerações Finais}

Pretendeu-se, nesta pesquisa, verificar como a audiodescrição de imagens estáticas no livro didático dos anos finais do Ensino Fundamental contribuiu para o acesso ao conhecimento de estudantes com baixa visão.

O debate concernente à inclusão escolar das pessoas com deficiência tem sido, nos últimos anos, demasiadamente abordado em diversos países. No Brasil, pesquisas recentes apontaram para práticas pedagógicas inclusivas, atendimento educacional especializado, tecnologia assistiva referenciada no modelo do desenho universal, acessibilidade, entre outras.

Diante disso, levando em consideração que ainda são inúmeras as questões que impedem e limitam o acesso pleno de estudantes com deficiência visual ao material didático, sobretudo às imagens estáticas que ornamentam e contribuem para a resolução de exercícios, esta pesquisa dedicou-se à audiodescrição de imagens estáticas no livro didático de Língua Portuguesa nos anos finais do Ensino Fundamental.

Dessa maneira, constatamos que o livro didático se configura para além de um dispositivo contributivo no processo de ensino-aprendizagem. É um instrumento que aponta para o futuro dos estudantes, um recurso que permite ser revisto em casa, a fim de buscar informações implícitas para a resolução dos exercícios. Todavia, para que isso ocorra com autonomia e independência, de forma a permitir que uma pessoa com deficiência visual tenha acesso de forma plena aos conhecimentos, as barreiras para a aprendizagem necessitam ser erradicadas. E, dessa assertiva, a audiodescrição de imagens, enquanto tecnologia assistiva, apresentou-se como um recurso que beneficia não só os próprios estudantes com baixa visão, mas também toda e qualquer pessoa que precisa aprender, conhecer, desenvolver e empoderar. 
O recurso da audiodescrição, nesse sentido, relacionado às imagens, contribuiu não só para que os estudantes apreendessem o que propunha o exercício, mas também para que tivessem acesso ao conhecimento, construindo, com desempenho, habilidade e empoderamento, as suas respostas.

Ter acesso à imagem com o recurso comunicacional da audiodescrição contribuiu para trazer a certeza e eliminar dúvidas e ambiguidades, como foi possível depreender nos relatos dos estudantes. Dessa forma, puderam perceber informações relevantes para a resolução das atividades, como ficou evidente nas interpretações de Antônio, no Quadro 3, depois de ter tido acesso, com precisão, à imagem por meio da audiodescrição, e nas considerações de Daniel, no Quadro 5, quando reforçou que a imagem pode ser entendida melhor com o recurso.

A partir do que foi abordado, aponta-se como limites do estudo: a necessidade de uma maior população de estudantes com deficiência visual, a fim de nortear caminhos para a promoção da acessibilidade no contexto escolar. Além disso, seria importante desenvolver um estudo em sala de aula regular, vendo a audiodescrição acontecer em contexto naturalístico, sem haver intervenção do pesquisador. Infelizmente, pesquisas dessa natureza ainda são inviáveis, pois não se têm, em grande escala, livros didáticos com audiodescrição nas escolas disponíveis para os estudantes com deficiência visual.

Portanto, a audiodescrição é urgente no livro didático, em sala de aula, nos filmes exibidos pelo professor, nos slides que são lidos, nas reuniões pedagógicas, nas formações e capacitações docentes e em todo lugar que a inacessibilidade se faça presente, pois o estudante com deficiência visual, de modo processual, vai se dando conta dos recursos existentes que lhes são de direito, da tecnologia assistiva que pode corroborar seu aprendizado, do conteúdo que precisa ser adaptado, da acessibilidade comunicacional que deve ser oferecida e do conhecimento que lhes é postergado.

\section{Referências}

AINSCOW, Mel. Educação para todos: torná-la uma realidade. Comunicação apresentada no Congresso Internacional de Educação Especial, Birmingham, Inglaterra, Abril de 1995. Disponível em http://redeinclusao.web.ua.pt/docstation/com_docstation/20/fl_38.pdf Acesso em 10 mai. 2017.

ALVES, Jefferson Fernandes. Acessibilidade e Teatro: a presença das pessoas com deficiência visual como provocaçãa. Urdimento, Florianópolis, v.1, n.34, p. 161-171, mar./abr. 2019.

ALVES, Soraya Ferreira. TELES, Veryanne Couto. Audiodescrição simultânea: propostas metodológicas e práticas. Trab. Ling. Aplic., Campinas, n(56.2): 417-441, mai./ago. 2017.

AUMONT, Jacques. A imagem. Tradução: Estela dos Santos Abreu e Claudio C. Santoro Campinas, SP: Papirus, 2012.

BARDIN, Laurence. Análise de Conteúdo. São Paulo: Edições: 70, 2011. 
BERSCH, Rita. Introdução à tecnologia assistiva. Porto Alegre: RS. 2017.

BOGDAN, Roberto. BIKLEN, Sari Knopp. Investigação Qualitativa em Educação: uma introdução a teoria dos métodos. Portugal: Porto Editora. LDA. 1994.

BELMIRO, Celia Abicalil. A imagem e suas formas de visualidade nos livros didáticos de Português. Revista Educação \& Sociedade, ano XXI, no 72, agosto/2000.

BRASIL. Estatuto da criança e do adolescente: Lei federal $n^{\circ}$ 8069, de 13 de julho de 1990. Brasília/DF, 1990.

. Ministério de Educação e Cultura. LDB - Lei $n^{\circ}$ 9394/96, de 20 de dezembro de 1996. Estabelece as diretrizes e bases da Educação Nacional. Brasília: MEC, 1996.

CARVALHO, Rosita Edler. Removendo barreiras para a aprendizagem: educação inclusiva. Porto Alegre: Mediação, 2003.

CARVALHO, Wilson Júnior de Araújo. LEÃO, Bruna Alves. PALMEIRA, Charleston Teixeira. Locução e audiodescrição nos estudos de tradução audiovisual. Trab. Ling. Aplic., Campinas, n(56.2): 359-378, mai./ago. 2017.

DAVID, Jéssica. HAUTEQUESTT, Felipe. KASTRUP, Virginia. Audiodescrição de filmes: experiência, objetividade e acessibilidade cultural. Fractal: Revista de Psicologia, v. 24 - n. 1, p. 125-142, Jan./Abr. 2012.

EICH, Milena Schneid. SHULZ, Lisiane Ott. PINHEIRO, Luciana Santos. Audiodescrição como recurso de acessibilidade no livro didático de Língua Inglesa. Trab. ling. Aplic., Campinas, n (56.2): 443-459, mai./ago. 2017.

LIMA, Francisco José de LIMA, Rosângela Aparecida Ferreira, VIEIRA, Paulo André de Melo. O Traço de União da Áudio-descrição: versos e Controvérsias. Revista Brasileira de Tradução Visual, vol. I, 2009.

LIMA, Francisco José de LIMA, Rosângela Aparecida Ferreira. O direito das crianças com deficiência visual à áudio-descrição. Revista Brasileira de Tradução Visual, vol3, 2011.

MINAYO, Maria Cecília de Souza. Pesquisa social: teoria, método e criatividade. 33 ed. Petrópolis, RJ, 2013.

MOTTA, Lívia Maria Villela de M. Áudiodescrição na escola: abrindo caminhos para leitura de mundo. Campinas, SP: Pontes Editores, 2016.

MASINI, Elcie F. Salzano. A pessoa com visão subnormal: desenvolvimento de sua eficiência visual. In: MASINI, E.F.S. GASPARETO, M.E.R.F. (Orgs). Visão Subnormal: um enfoque educacional. São Paulo: Vetor, 2007.

NÓBREGA, Andreza. Caminhos Para Inclusão: uma Reflexão Sobre Áudio-Descrição No Teatro Infanto-Juvenil. Jaboatão dos Guararapes, PE: SESC, 2016.

OLIVEIRA, Eliana de. ENS, Romilda Teodora. ANDRADE, Daniela S. B. Freire. MUSSIS, Carlo Ralph de. Análise de conteúdo e pesquisa na área de educação. Revista Diálogo Educacional, Curitiba, v. 4, n. 9, p. 11-27, maio/ago. 2003.

REILY, Lucia. Escola Inclusiva: Linguagem e mediação. Campinas-SP: Papirus Editora, 2011. $4^{\mathrm{a}}$ ed.

RIBEIRO, Ernani Nunes. A imagem na relação de expressão com o texto escrito: contribuições da áudio-descrição para a aprendizagem de educandos surdos. Dissertação de Mestrado. Universidade Federal de Pernambuco, PPGEdu, CE, 2011. 
RODRIGUES Neidson. Educação: Da formação humana à construção do sujeito ético. Educação e Sociedade, ano 12, n. 76. out/ 2001.

SANTAELLA, Lúcia. NÖTH, Winfried. Imagem: cognição, semiótica, mídia. São Paulo: ILUMINURAS, 2014.

SASSAKI, Romeu Kazumi. Inclusão: construindo uma sociedade para todos. Rio de Janeiro: WVA, 2010.

SILVA, Luzia Guacira. Educação inclusiva: práticas pedagógicas para uma escola sem exclusões. 1. ed. - São Paulo: Paulinas, 2014.

SILVEIRA, Deise Mônica Medina. BONILLA, Maria Helena Silveira. Audiodescrição das imagens dos livros didáticos: uma proposta de análise comunicacional. Revista Educação Especial, v. 32, 2019 - Santa Maria/RS.

SOLÉR, Thais Regina Fernandes. PLAZZA, Tânia Guizzardi. EZEQUIEL, Lucimar Amaral. Formação requerida para o professor especializado atender o aluno com visão subnormal na escola regular. In: MASINI, E.F.S. GASPARETO, M.E.R.F. (Orgs). Visão Subnormal: um enfoque educacional. São Paulo: Vetor, 2007.

SOUZA, Ivan Vale de. Audiodescrição: o que é? Como se faz? Revista EDaPECI. São Cristóvão (SE) v.17. n. 3, p. 34-45 set./dez. 2017.

SNYDER, Joel. Áudio-descrição: uma ajuda para a literacia. Revista Brasileira de Tradução Visual (RBTV), Vol. 6, 2011.

YIN, Roberto K. Estudo de Caso: planejamento e métodos. Trad. Daniel Grassi. $2^{\text {a }}$ Edição - Porto Alegre: Bookman, 2001.

Recebido em: 03/05/2020

Aprovado em:11/09/2020 